\title{
The R. L. Jaggers Site (41FK3): An Early Caddo Period Settlement and Cemetery in the Sulphur River Basin, Franklin County, Texas
}

Timothy K. Perttula

Heritage Research Center, Stephen F. Austin State University

Follow this and additional works at: https://scholarworks.sfasu.edu/ita

Part of the American Material Culture Commons, Archaeological Anthropology Commons, Environmental Studies Commons, Other American Studies Commons, Other Arts and Humanities Commons, Other History of Art, Architecture, and Archaeology Commons, and the United States History Commons

Tell us how this article helped you.

This Article is brought to you for free and open access by the Center for Regional Heritage Research at SFA ScholarWorks. It has been accepted for inclusion in Index of Texas Archaeology: Open Access Gray Literature from the Lone Star State by an authorized editor of SFA ScholarWorks. For more information, please contact cdsscholarworks@sfasu.edu. 


\section{The R. L. Jaggers Site (41FK3): An Early Caddo Period Settlement and Cemetery in the Sulphur River Basin, Franklin County, Texas \\ Creative Commons License \\ (c) (1) (8)}

This work is licensed under a Creative Commons Attribution-NonCommercial 4.0 International License 


\title{
The R. L. Jaggers Site (41FK3): An Early Caddo Period Settlement and Cemetery in the Sulphur River Basin, Franklin County, Texas
}

\author{
Timothy K. Perttula
}

\section{INTRODUCTION}

The R. L. Jaggers site is an Early Caddo period (ca. A.D. 1000-1200) settlement and cemetery in the Sulphur River basin Post Oak Savannah in East Texas (Figure 1). The University of Texas (UT) completed archaeological investigations at the site in 1930. The site has received no professional archaeological investigations since that time. Thurmond $(1990: 152,155)$ has provided a short and cursory review of the funerary offerings recovered in the excavated burials at the site.

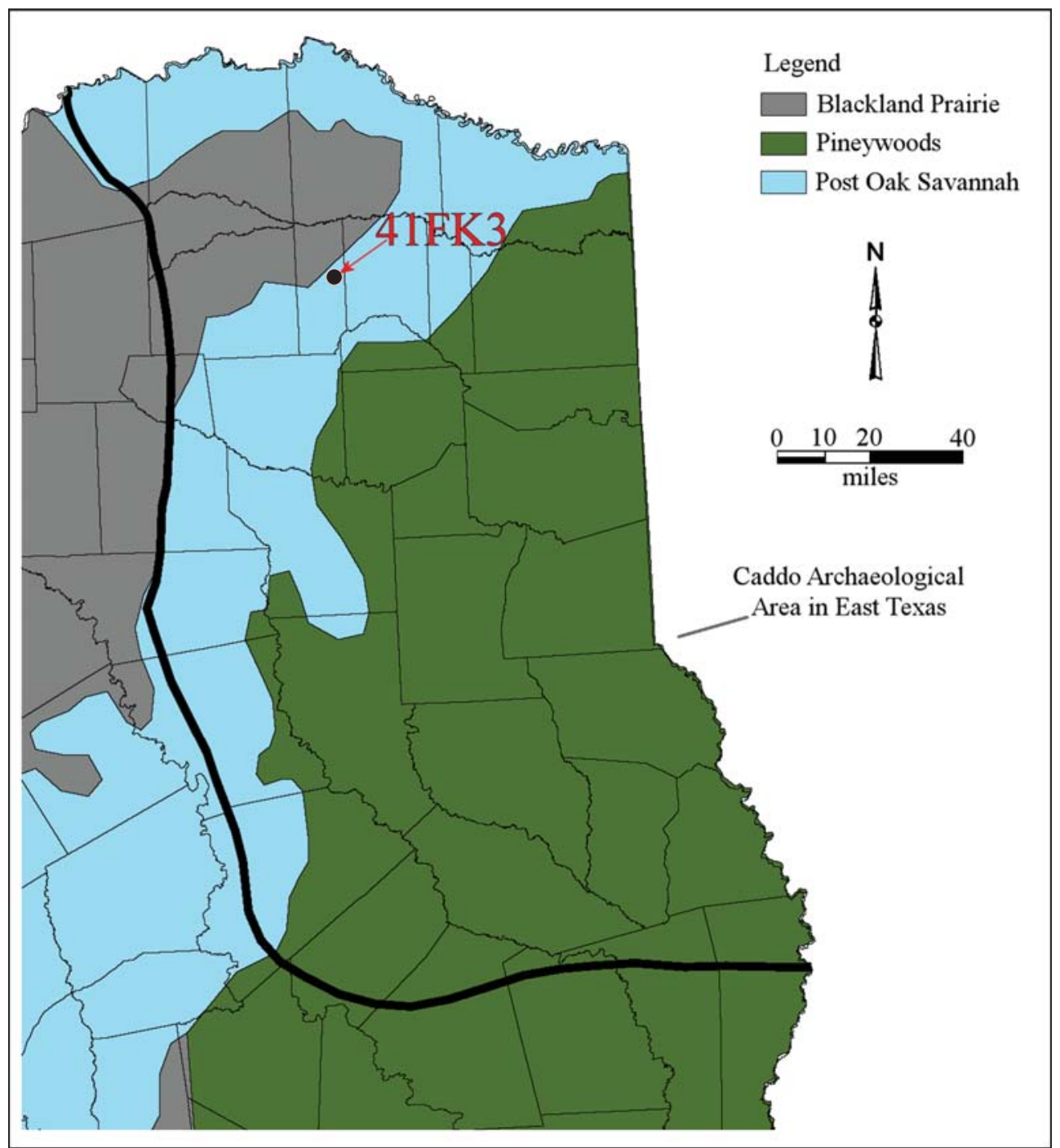

Figure 1. Location of the R. L. Jaggers site in East Texas. 


\section{SITE SETTING}

The site is on a low alluvial terrace on the north side of Ripley Creek, a tributary of White Oak Creek in the Sulphur River basin (Figure 2). Jackson (1930) noted that ceramic vessels had been reported to have been washed up or plowed up from the terrace in the past, including in 1928 from a ditch and eroded area just south of the small ancestral Caddo cemetery that was discovered in 1930 at the site.

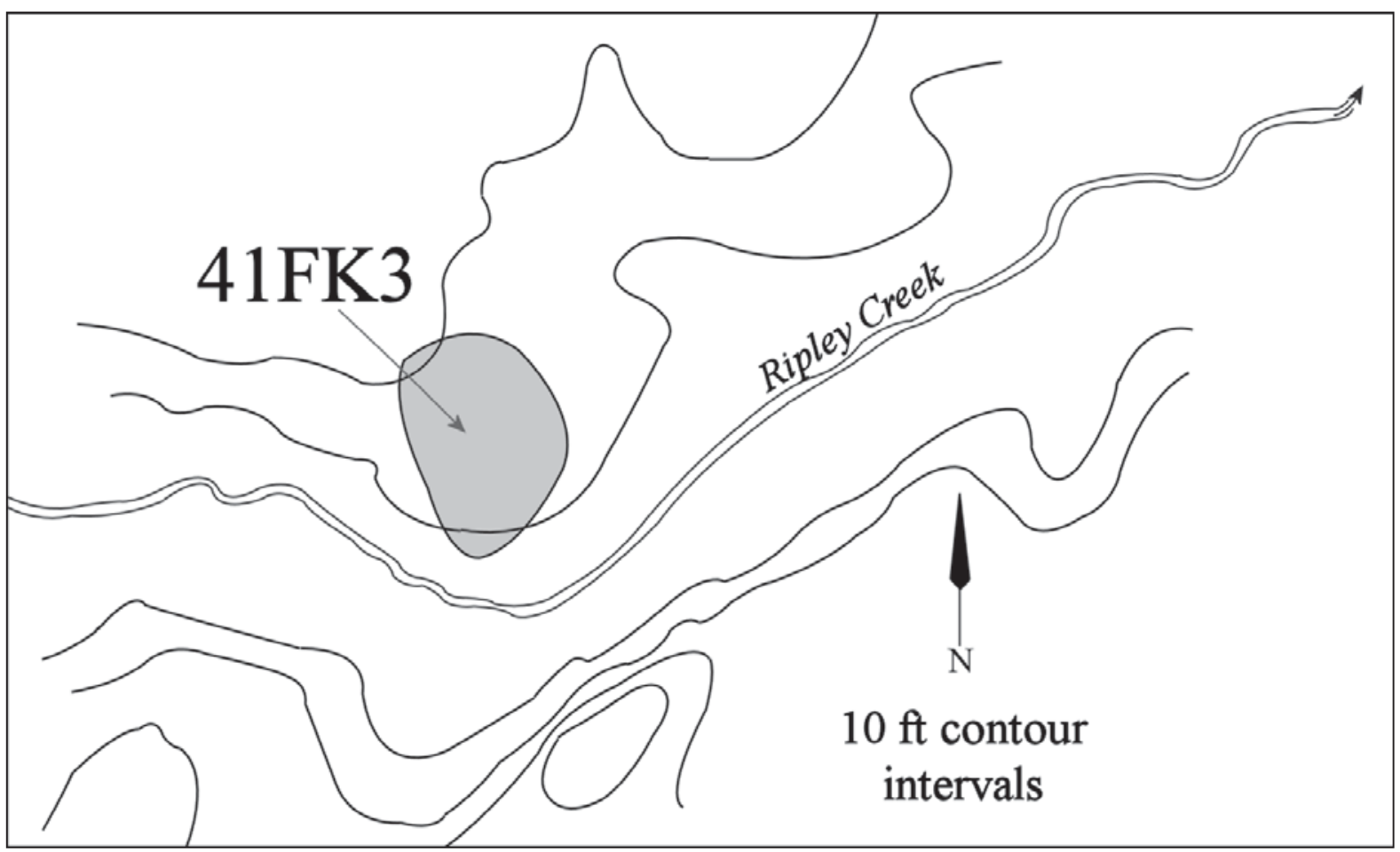

Figure 2. The R. L. Jaggers site on Ripley Creek in the Sulphur River Basin.

UT archaeologists investigated a ca. $42 \times 50 \mathrm{ft}$. area of the terrace and in addition to discovering habitation deposits of Late Archaic, Woodland, and Early Caddo period age (see below), they identified four burial features (Burials 1-4) (Figure 3). Burial 1 was a cremation, consisting of a ca. 25 x $48 \mathrm{~cm}$ pile of charred human remains at ca. $99 \mathrm{~cm}$ bs. Associated funerary offerings included two ceramic vessels - both engraved fine wares (see below) - a ground stone celt that had been broken in two, and a Gary dart point.

Burials 2-4 at the R. L. Jaggers site were extended supine interments, but in each case the burials were oriented in different directions, with the head of the deceased either facing southwest (Burial 2), south (Burial 3), or west-northwest (Burial 4) (see Figure 3) (Jackson 1930:2-3). Burial 2, discovered at a depth of ca. $76 \mathrm{~cm}$ bs, had four associated ceramic vessel funerary offerings (two fine ware vessels and two plain vessels). Burial 3 was at a depth of ca. $63 \mathrm{~cm}$ bs; the funerary offerings included three vessels (one fine ware vessel and two utility ware vessels), a celt, and one Gary dart point. Burial 4 was buried only at a depth of ca. $41 \mathrm{~cm}$ bs. Funerary offerings included a cache of 10 lithic flakes and two Gary dart points. Unless the association is fortuitous, the recovery of Gary points in two of the Early Caddo period burials suggests that this dart point type was still in use after ca. A.D. 1000 by Caddo peoples in East Texas. 


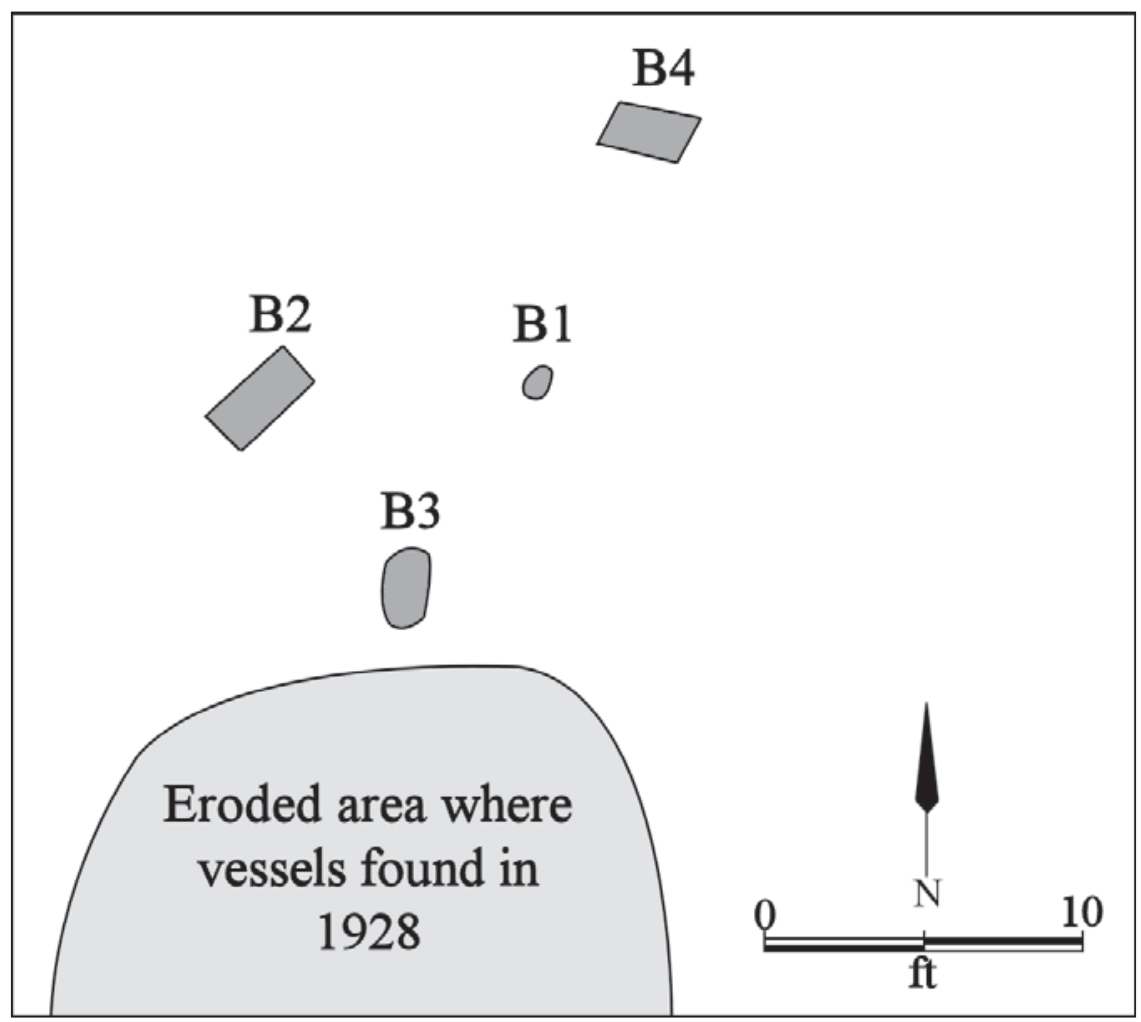

Figure 3. Burials 1-4 at the R. L. Jaggers site.

\section{ARTIFACT ASSEMBLAGE}

The artifact assemblage from the R. L. Jaggers site includes a diverse array of chipped stone tools $(\mathrm{n}=93)$, ground stone tools $(n=13)$, and ceramic artifacts. The ceramic artifacts from the site include 13 vessels, 203 plain and decorated ceramic sherds, and one long-stemmed Red River pipe sherd.

\section{Chipped Stone Tools}

More than 76 percent of the chipped stone tools in the R. L. Jaggers collection are dart points (Table 1), followed by bifaces discarded during the projectile point manufacturing process (12 percent), and expedient flake tools ( 7.5 percent). About 58 percent of the chipped stone tools are made from local coarse- and fine-grained quartzite, and another 9.7 percent of the chipped stone tools are made on local petrified wood and earth-toned cherts (Table 1). The remainder of the chipped stone tools ( 32 percent) are on lithic raw materials that were available in the Red River gravels, including various high-quality cherts and novaculite that likely originated in the Ouachita Mountains of southeast Oklahoma (Banks 1990). 
Table 1. Chipped stone tools from the R. L. Jaggers site.

\begin{tabular}{|c|c|c|c|c|c|c|}
\hline Tool types & Qtz. & Nov. & $\begin{array}{l}\text { Red River chert } \\
\text { and jasper }\end{array}$ & PW & $\begin{array}{l}\text { Local } \\
\text { chert }\end{array}$ & $\mathrm{N}$ \\
\hline \multicolumn{7}{|l|}{ Arrow Points } \\
\hline Alba & - & - & 1 & - & - & 1 \\
\hline Catahoula & 1 & - & 1 & - & - & 2 \\
\hline Bifacial adze & - & - & - & - & 1 & 1 \\
\hline \multicolumn{7}{|l|}{ Bifaces } \\
\hline Early and mid-stage & 6 & 1 & 3 & 1 & - & 11 \\
\hline \multicolumn{7}{|l|}{ Dart Points } \\
\hline cf. Bulverde & - & - & 2 & - & - & 2 \\
\hline Delhi & - & 1 & 1 & - & - & 2 \\
\hline Gary & 31 & 3 & 6 & 1 & $3 *$ & 43 \\
\hline Gary preform & 3 & - & - & - & - & 3 \\
\hline Kent & - & - & 5 & - & - & 5 \\
\hline Morrill & - & - & - & 1 & - & 1 \\
\hline Trinity & 1 & - & - & - & - & 1 \\
\hline Yarbrough & 3 & - & 1 & - & - & 4 \\
\hline UID expanding stem & 1 & - & - & - & - & 1 \\
\hline $\begin{array}{l}\text { UID parallel stem with } \\
\text { grinding }\end{array}$ & - & - & 1 & - & - & 1 \\
\hline UID blade/tip & 3 & - & 2 & - & 1 & 6 \\
\hline UID stem & - & - & $1 * *$ & - & - & 1 \\
\hline Subtotal & 42 & 4 & 19 & 2 & 4 & 71 \\
\hline \multicolumn{7}{|l|}{ Flake tools } \\
\hline Unilateral & 3 & - & 1 & - & - & 4 \\
\hline Bilateral & 1 & - & 1 & - & 1 & 3 \\
\hline Unifacial Gouge & 1 & - & - & - & - & 1 \\
\hline Totals & 54 & 5 & 25 & 3 & 6 & 93 \\
\hline
\end{tabular}

Qtz=quartzite; Nov.=novaculite; $P W=$ petrified wood

UID=inidentified

*includes one point made from baked shale

**Alibates?

The variety of dart points recovered in the UT investigations at the R. L. Jaggers site suggest the site was used during both the Late Archaic (ca. 5000-2500 years B.P.) and Woodland (ca. 2500-1250 years B.P.) periods (Perttula 2013:Figure 2), and one parallel-stemmed dart point with lateral stem grinding suggests some limited use of the site prior to about 8000 years B.P. The most intensive use of the site before the Early Caddo period occupation took place during the Woodland period, as Gary points, Gary point preforms, and Kent dart points - recognized Woodland period temporal diagnostics-comprise more than 71 percent of the dart points and more than 82 percent of the typologically identifiable dart points (see Table 1). 
In the Late Archaic dart points, quartzite (40 percent) and Red River gravel cherts and jasper (40 percent) were the most common lithic raw materials used in point manufacture, along with novaculite (10 percent) and petrified wood (10 percent (see Table 1). By contrast, the Woodland period dart points in the R. L. Jaggers assemblage are predominantly made from local quartzite (67 percent), with much lower percentages of Red River gravel cherts and jasper (21 percent), novaculite (6 percent), or local cherts (4 percent) and petrified wood (2 percent (see Table 1).

The Gary points in the R. L. Jaggers assemblage have stem widths that range from 10.9-19.2 mm, with a mean stem width of $14.3 \mathrm{~mm}$. One of the Gary points from the site, made from a locally chalky pinkish orange baked shale, apparently from local baked and fused rocks in the Wilcox Group (Brown 1976:192194), has been carved to shape rather than percussion-flaked. It has a $16.2 \mathrm{~mm}$ stem width.

The three arrow points in the R. L. Jaggers chipped stone tools are early Caddo styles: Alba and Catahoula (see Table 1). Red River gravel cherts and jasper represent 67 percent of the arrow points, with the remaining arrow point made from a local quartzite.

Other chipped stone tools include a bifacial adze and a unifacial gouge (see Table 1); they are made of local lithic raw materials. There is also a pyramidal core in the collection. It is on a coarsely-grained whitish-gray quartzite.

\section{Ground Stone Tools}

There are several kinds of ground stone tools in the R. L. Jaggers site collection, including a ferruginous sandstone grinding slab and basin as well as a ferruginous sandstone mortar/grinding basin, a ferruginous sandstone bi-pitted stone, and two quartzite manos and bi-pitted stones; these tools have grinding on both cobble surfaces. There are also two quartzite polished pebbles (25-34 $\mathrm{mm}$ in diameter) and a small pebble (20 $\mathrm{mm}$ in diameter) of the local chalky pinkish-orange baked shale.

The five celts from Ouachita Mountains greenstone, siliceous shale, and quartzitic sandstone are the most common ground stone tool at the R. L. Jaggers site (Figure 4a-e). Four are from the surface and the fifth was among the funerary offerings in Burial 3 (Figure 4e). One celt fragment (78+ x 44 x $28 \mathrm{~mm}$ in length, width, and thickness) is a rectangular-shaped preform with edge crushing and flaking at the poll end, and polishing on only one face (Figure 4a). Another celt ( 77 x $43 \mathrm{~mm}$ in length and width), with a finished and polished bit, still has substantial areas of cortex on one face that had not been removed through either percussion flaking or pecking (Figure 4c). The other three celts have bifacially polished bits, rounded poll ends, and pecked bodies (Figure 4b, d-e).

The interior surface of a single thin slab of hematite has horizontal and diagonal scratches and scored marks from its use as a source of pigment (Figure 5). The stone is $85 \times 57 \times 9.5 \mathrm{~mm}$ in length, width, and thickness.

\section{Ceramic Vessels}

There are 13 Early Caddo period vessels from the excavations at the R. L. Jaggers site. This includes nine vessels from Burials 1-3 and four vessels treated as isolated finds; most likely these four vessels are also from burials but were not recognized as such by the UT field crew.

The first vessel in Burial 1 at the R. L. Jaggers site is a uniquely-decorated bottle with horizontal engraved lines on the neck and a tool punctated body; the punctations are on a raised four-sided area on the bottle body and the rest of the bottle body is plain (Thurmond 1990:Table 30). It is $23.5 \mathrm{~cm}$ in height, with a tapered neck, has a $4.2 \mathrm{~cm}$ orifice diameter, and a maximum body diameter of $16.8 \mathrm{~cm}$. 


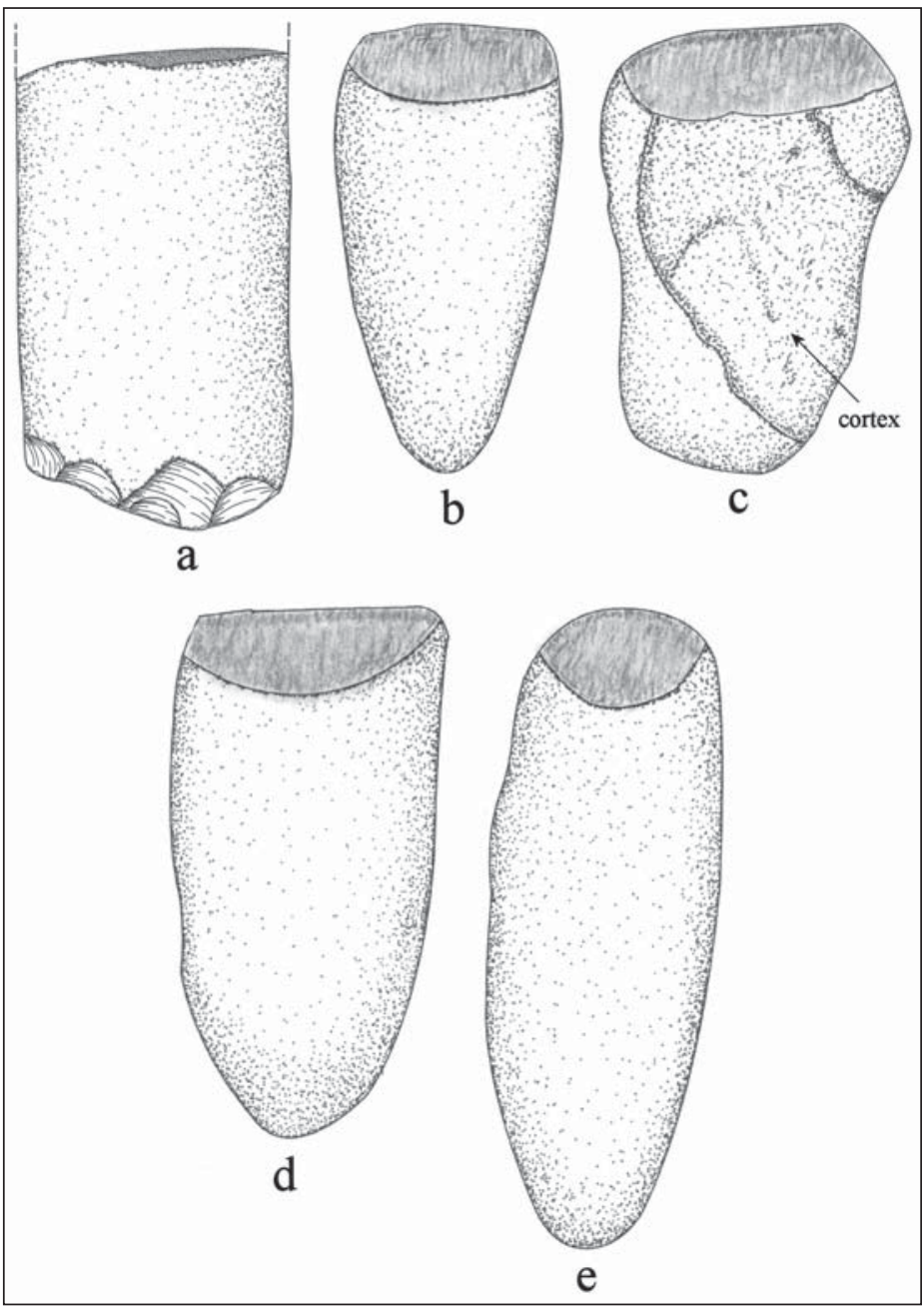

Figure 4. Celts from the R. L. Jaggers site: a-d, from surface contexts; e, from Burial 3.

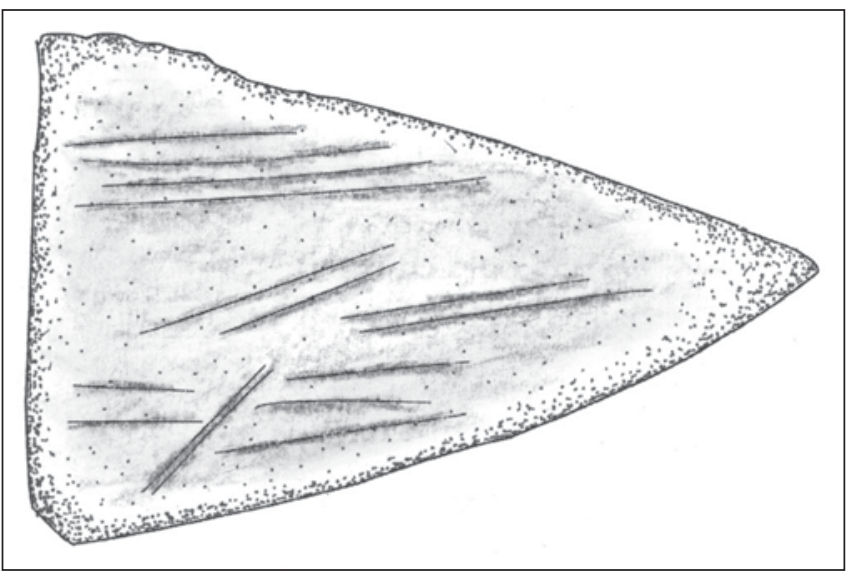

Figure 5. Hematite pigment stone from the R. L. Jaggers site. 
Vessel 2 in Burial 1 is a small Hickory Engraved jar (Figure 6; see also Suhm and Jelks [1962:Plate $36 \mathrm{~b}]$ ) that is $11.0 \mathrm{~cm}$ in height, with a $5.2 \mathrm{~cm}$ orifice diameter, and it is $8.5 \mathrm{~cm}$ in maximum body diameter; there are fire clouds on the rim. The jar has four horizontal engraved lines on the rim and six horizontal engraved lines on the upper body.

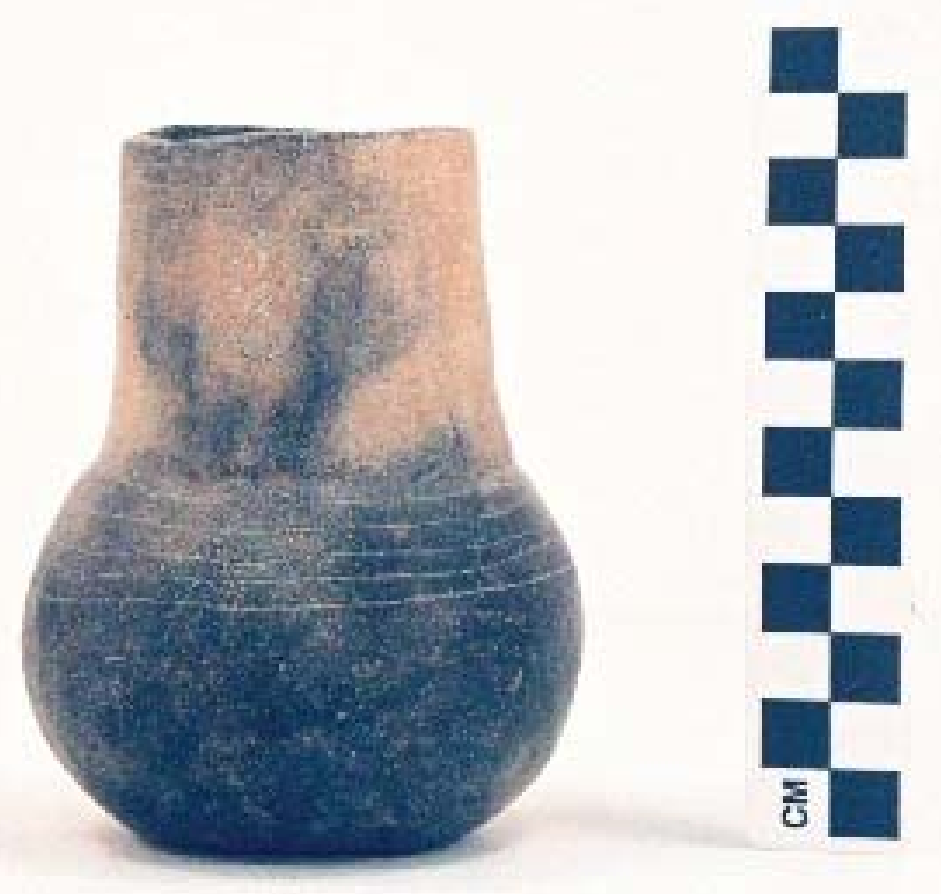

Figure 6. Hickory Engraved jar, Burial 1, Vessel 2.

The first vessel in Burial 2 is a Spiro Engraved carinated bowl with an inverted rim, with an engraved design on the rim panel. The carinated bowl is $7.4 \mathrm{~cm}$ in height, with a $14.5 \mathrm{~cm}$ orifice diameter, and a maximum body diameter of $15.2 \mathrm{~cm}$. The rim is decorated with opposed concentric semi-circles and spirals (with associated excised triangles) divided by sets of two vertical engraved lines (Figure 7a-b). The innermost of the repeated set of semi-circles is excised.
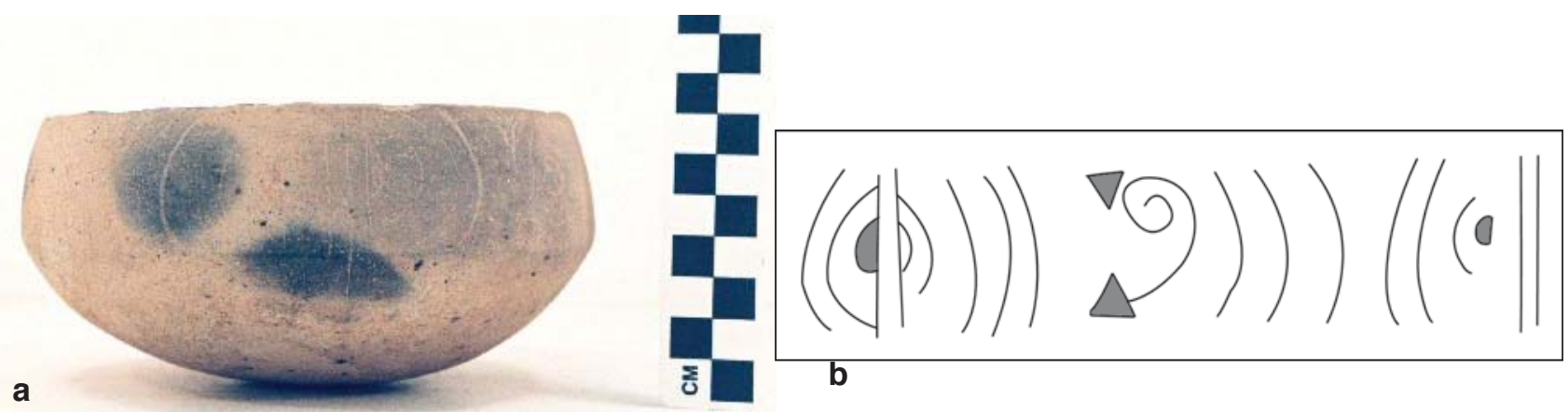

Figure 7. Spiro Engraved carinated bowl, Burial 2, Vessel 4: a, side view; b, decorative elements.

The second vessel in Burial 2 is a plain carinated bowl (Figure 8). This vessel is $9.5 \mathrm{~cm}$ in height, has a $16.2 \mathrm{~cm}$ orifice diameter, and is $15.2 \mathrm{~cm}$ in maximum body diameter. 

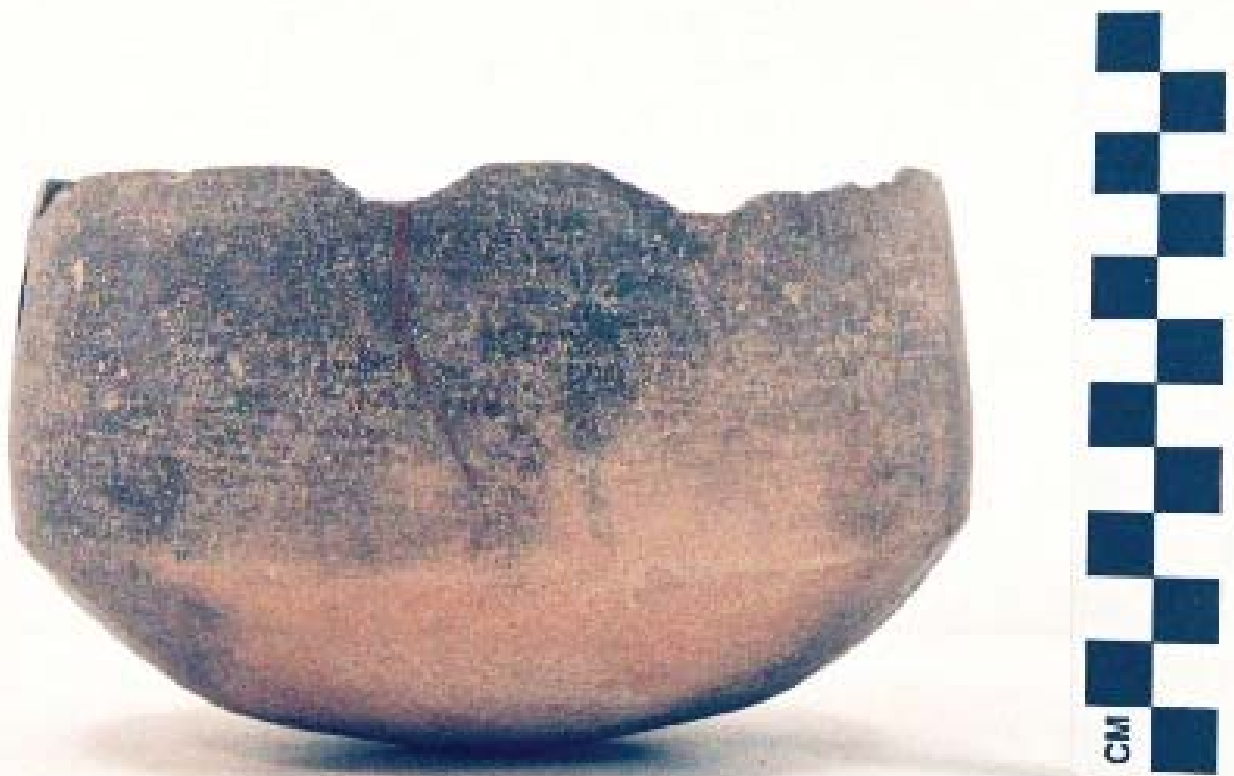

Figure 8. Plain carinated, Burial 2, Vessel 5.

The third vessel in Burial 2 is a Spiro Engraved bottle with a short tapered neck (Figure 9a). It stands $22.1 \mathrm{~cm}$ in height, has a $4.5 \mathrm{~cm}$ orifice diameter, and a maximum body diameter of $14.5 \mathrm{~cm}$. The vessel body is decorated with alternating and opposed concentric semi-circles and nested triangles filled with concentric circles (Figure 9a-b).

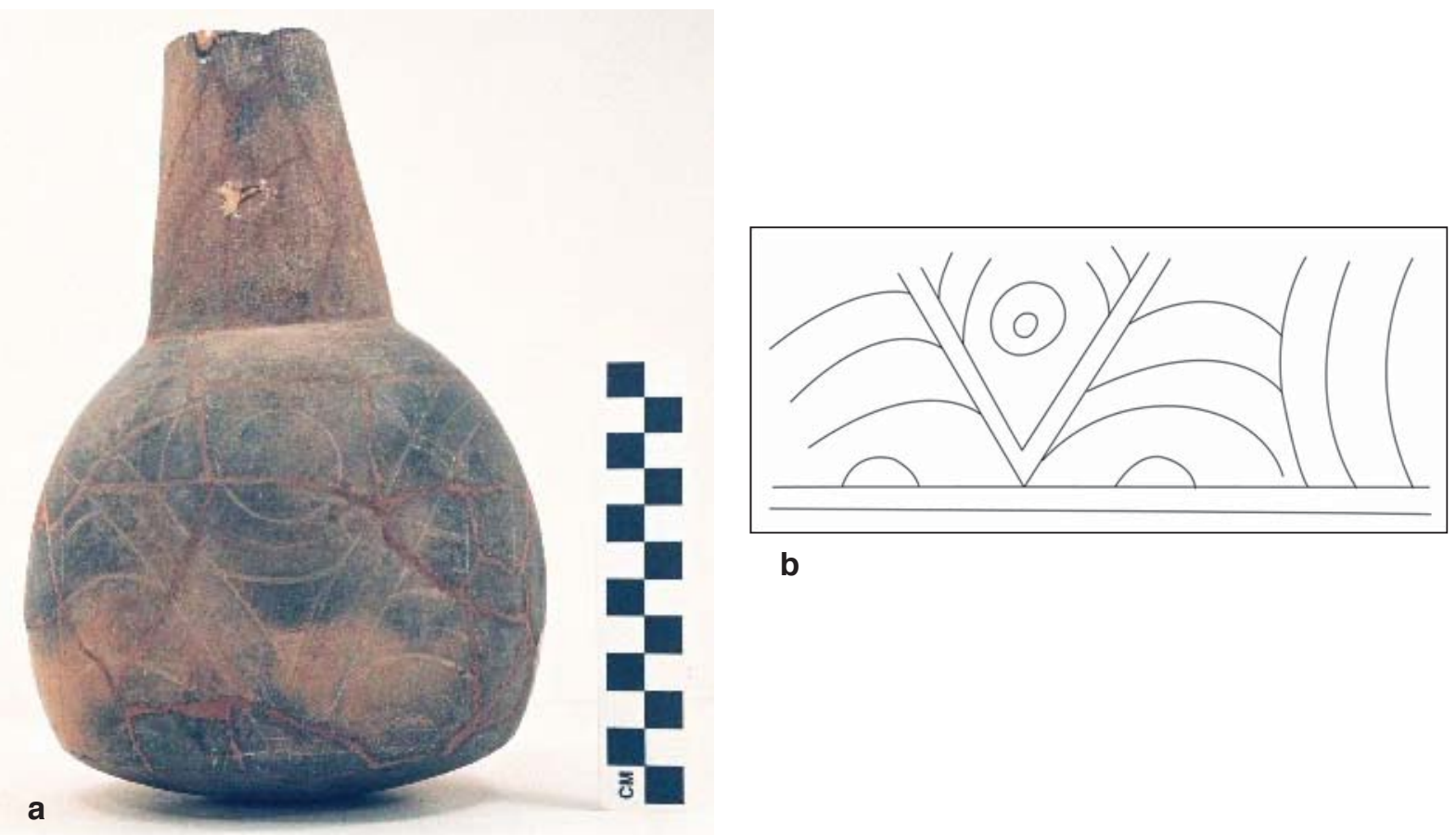

Figure 9. Spiro Engraved bottle, Burial 2, Vessel 6: a, side view; b, decorative elements. 
The last vessel included in Burial 2 at the R. L. Jaggers site is a plain jar or beaker (Figure 10). It has a "flattened base and squared lip" (Thurmond 1990:Table 30).

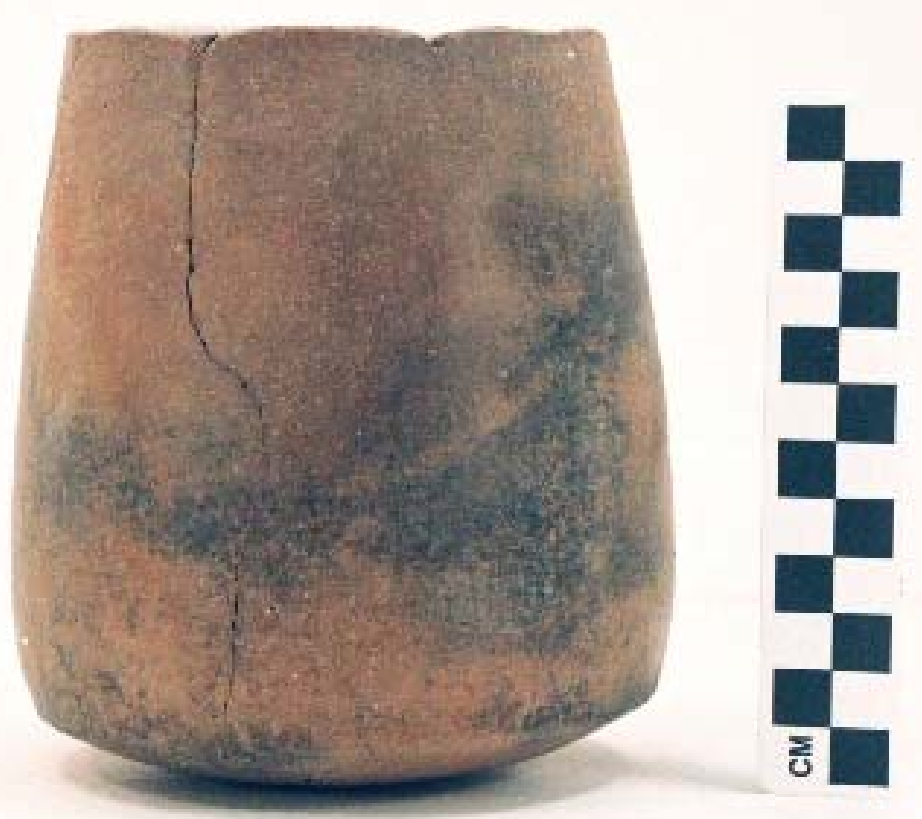

Figure 10. Plain jar or beaker, Burial 2, Vessel 7.

The first vessel in Burial 3 is a Spiro Engraved bowl with opposed lip tabs (Figure 11a). The bowl is $8.4 \mathrm{~cm}$ in height and has a $11.1 \mathrm{~cm}$ orifice diameter. The vessel is decorated with three horizontal engraved lines, and the vessel body has sets of engraved concentric semi-circles that are pendant from the rim; the innermost semi-circle is excised and there are sets of short vertical engraved lines below the semi-circles (Figure 11b). The sets of concentric semi-circles are divided by sets of five vertical engraved lines.

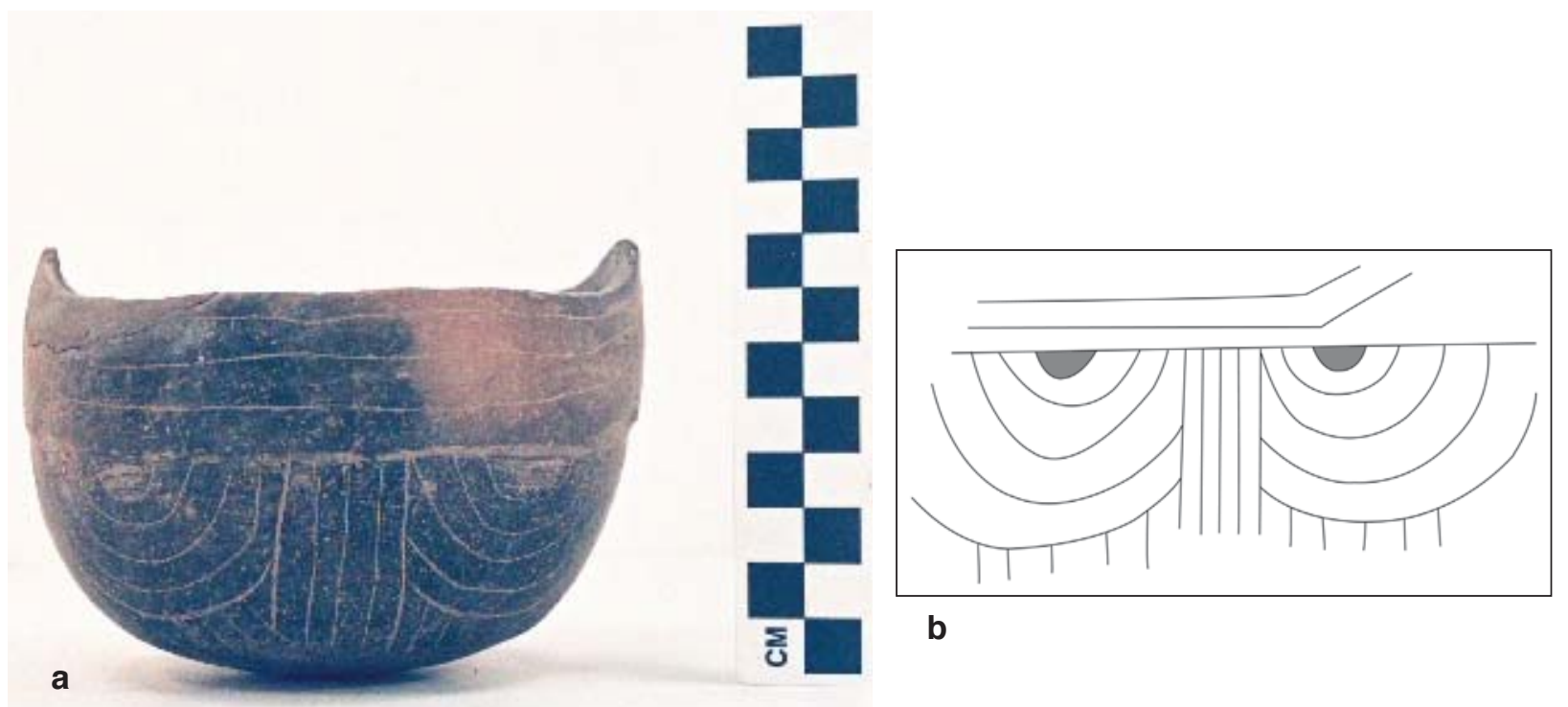

Figure 11. Spiro Engraved bowl with opposed tab tails, Burial 3, Vessel 9: a, side view; b, decorative elements. 
The two other vessels in Burial 3 are utility wares. The first is a probable Davis Incised jar with five horizontal incised lines on the rim (see Suhm and Jelks 1962:35); the body is plain. The jar stands $12.6 \mathrm{~cm}$ in height and has a $12.4 \mathrm{~cm}$ orifice diameter. The last vessel in Burial 3 is a Kiam Incised bowl. It has eight horizontal incised lines on the rim and a continuous series of vertical incised lines on the body (see Suhm and Jelks 1962:Plate 45a, d). The bowl is $9.3 \mathrm{~cm}$ in height and has a $10.1 \mathrm{~cm}$ orifice diameter; maximum body diameter is $11.3 \mathrm{~cm}$.

An additional four vessels from the R. L. Jaggers site are listed as isolated finds in the TARL inventory. It is probable that the vessels are from burial features that were not recognized by the UT field crew. The first of the isolated find vessels is a probable Davis Incised jar with three horizontal incised lines on the rim and a plain body. It is $9.9 \mathrm{~cm}$ in height and has a $10.6 \mathrm{~cm}$ orifice diameter. Thurmond (1990:Table 31) describes the vessel as a "Williams Plain-like jar...[with a] very thick, extended base."

The second isolated find vessel is a Hickory Engraved jar with seven horizontal engraved lines on the rim and opposed suspension holes. The jar is $10.9 \mathrm{~cm}$ in height and has a $9.1 \mathrm{~cm}$ orifice diameter. The third isolated find vessel at the R. L. Jaggers site is a small jar with three horizontal incised lines on the rim, and a row of fingernail punctates lie below the bottom incised line and mark the rim-body juncture. This jar is only $5.8 \mathrm{~cm}$ in height and has a $6.6 \mathrm{~cm}$ orifice diameter.

The last of the isolated find vessels is a Spiro Engraved bowl with opposed lip tabs (see Figure 11a and Suhm and Jelks [1962:Plate 74b-e] for vessel form). There are three horizontal engraved lines on the rim, while the vessel body is divided into a series of panels by either sets of vertical engraved lines or panels filled with small excised punctations (Figure 12). The main panels have sets of bifurcating diagonal engraved lines, with upper and lower sets pf concentric circles and semi-circles. The innermost circles are filled with small excised punctations.

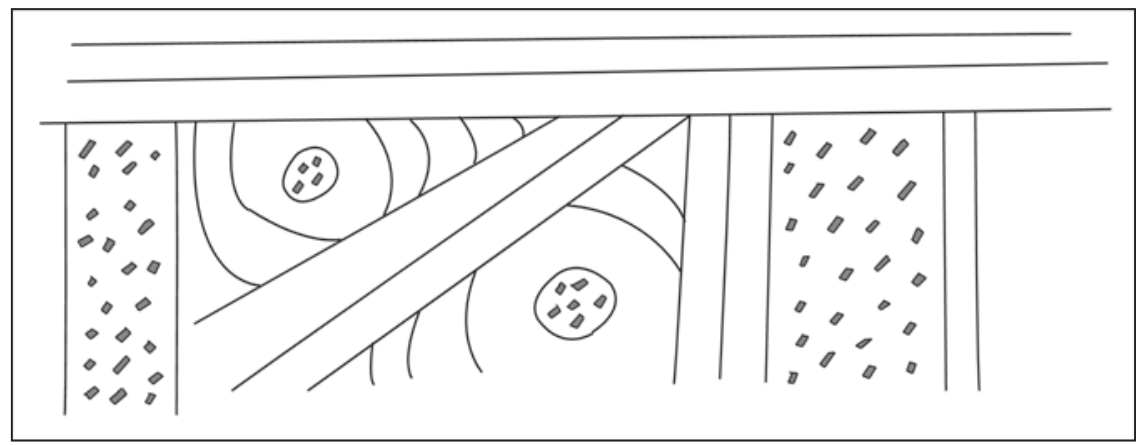

Figure 12. Decorative elements on Spiro Engraved bowl with opposed tab tails, Vessel X-1.

\section{Ceramic Sherds}

There are only 160 plain and 43 decorated sherds in the R. L. Jaggers collection (Table 2). Most of the sherds appear to be part of the Early Caddo period occupation at the site, but a few decorated sherds (see below) are indicative of a post-A.D. 1430 Late Caddo period, Titus phase occupation at the site as well. 
Table 2. Temper identified in sherds from the R. L. Jaggers site.

\begin{tabular}{lccrr}
\hline Temper & Plain ware & Utility ware & Fine ware & N \\
\hline grog & 146 & 23 & 11 & 180 \\
bone & 14 & 6 & 3 & 23 \\
\hline Totals & 160 & 29 & 14 & 203 \\
\hline
\end{tabular}

About 89 percent of the sherds from the site are from vessels tempered with grog or crushed sherds; the remainder are tempered with crushed burned bone (see Table 2). Both the utility ware (21 percent) and fine ware (21 percent) sherds have a higher proportion of bone temper use than do the plain wares (9 percent). The overall proportions of grog temper and bone temper use in vessel manufacture at the R. L. Jaggers site is consistent with Caddo sherd assemblages across East Texas (Perttula 2015).

The utility ware sherds are from vessels with wet paste decorative elements, including appliqued, appliqued-punctated, brushed, incised, incised-punctated, and punctated elements (Table 3). The appliqued, appliqued-punctated, and brushed sherds are likely from Late Caddo, Titus phase, utility ware vessels, including Harleton Appliqued, McKinney Plain, and Bullard Brushed. The remainder of the utility wares represent the Early Caddo period occupation at the site. The one incised rim is from a Dunkin Incised jar (Figure 13g).

Table 3. Decorative elements on utility wares from the R. L. Jaggers site.

\begin{tabular}{llll}
\hline Decorative element & Rim & Body
\end{tabular}

appliqued

appliqued node

appliqued ridge, straight

$\begin{array}{lll}- & 1\end{array}$

appliqued-punctated

tool punctated row at rim-body juncture

$-$

and vertical appliqued ridges

tool punctated row at rim-body juncture

$-\quad 1$

and horizontal appliqued fillet

brushed, parallel

incised

diagonal opposed lines

1

$-$

parallel lines

straight lines

\section{incised-punctated}

diagonal incised lines-tool punctated row opposed incised lines and overlying horizontal tool punctated rows

1

2


Table 3. Decorative elements on utility wares from the R. L. Jaggers site, cont.

\begin{tabular}{lccc}
\hline Decorative element & Rim & Body & N \\
\hline punctated & & & \\
fingernail punctated rows & - & 3 & 3 \\
fingernail punctated row under lip & 1 & - & 1 \\
tool punctated row & - & 2 & 2 \\
\hline Totals & 2 & 27 & 29 \\
\hline
\end{tabular}

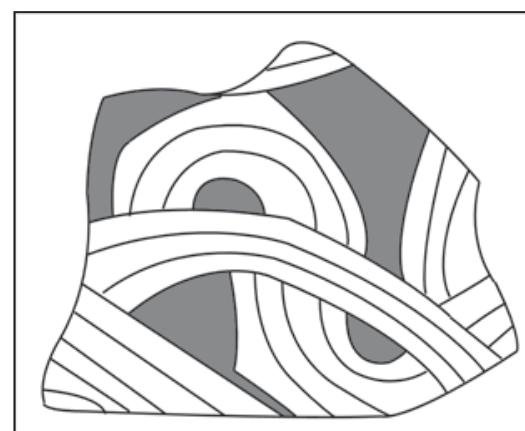

a
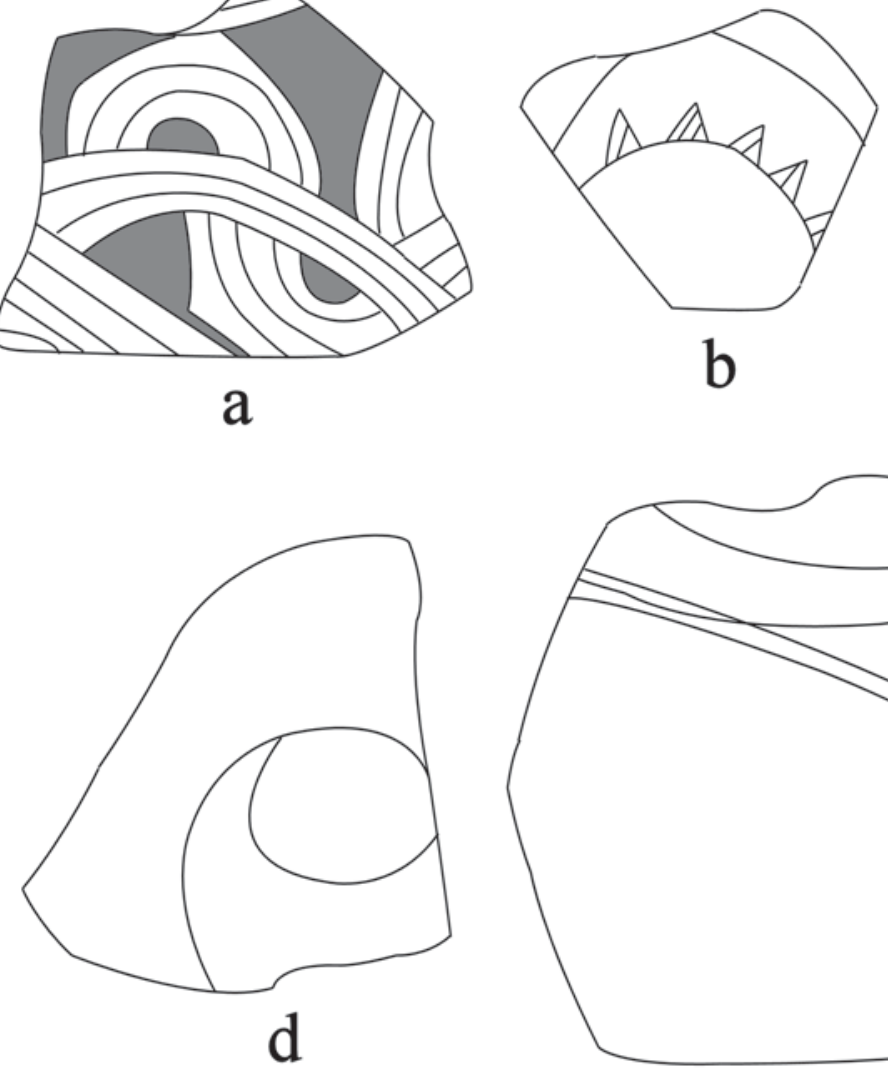

b
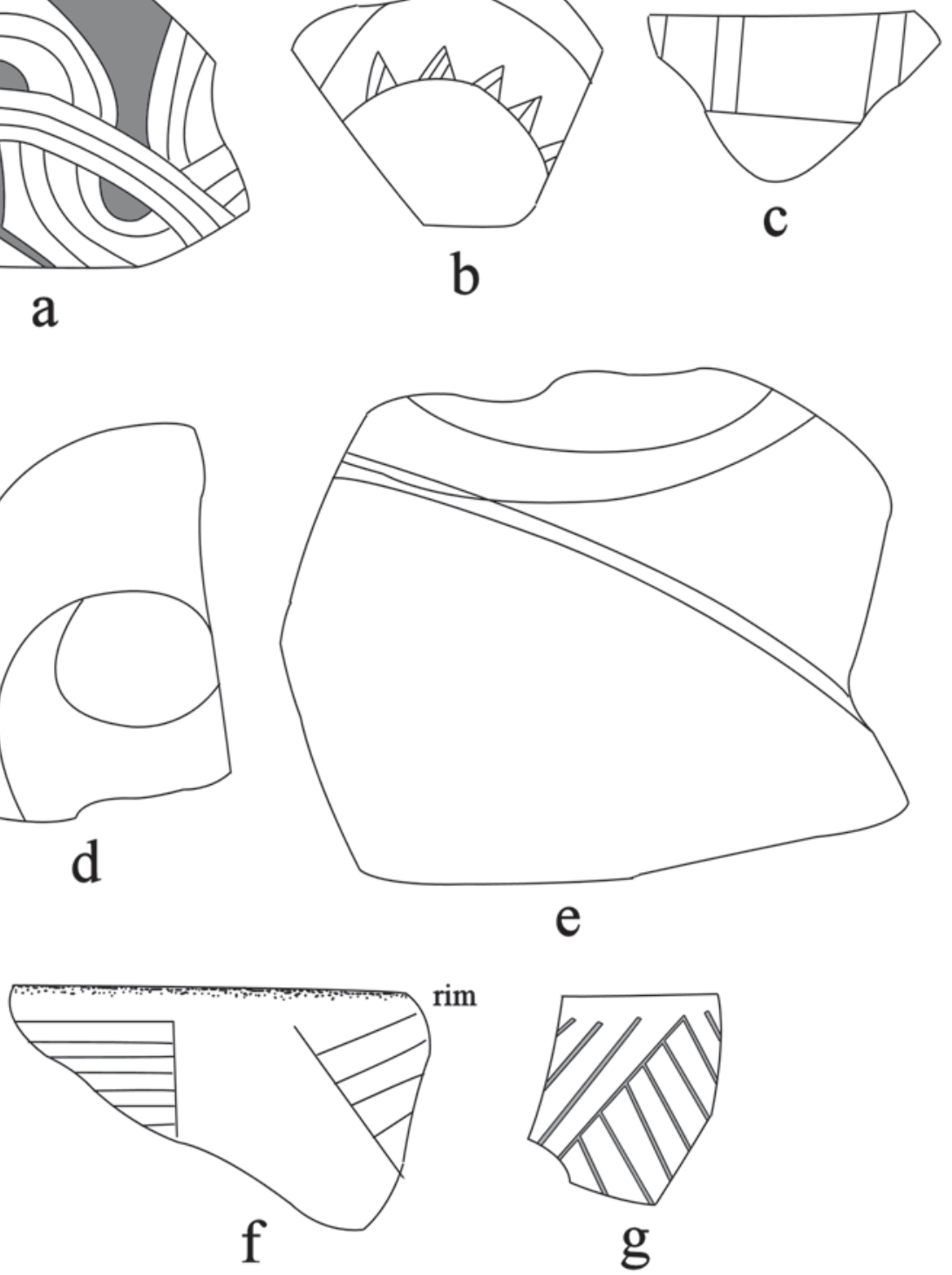

Figure 13. Decorative elements on selected sherds: a-f, engraved rim and body sherds; $g$, incised rim sherd. 
The only rim sherds in the fine wares from the R. L. Jaggers site (Table 4) are from a vessel section comprised of 11 rim and body sherds from a bone-tempered carinated bowl. The vessel section has diagonal and horizontal hatched pendant triangles (see Figure 13f); the engraved lines have a red pigment rubbed in the engraved lines.

Table 4. Decorative elements on fine wares from the R. L. Jaggers site.

\begin{tabular}{llll}
\hline Decorative element & Rim & Body & N \\
\hline $\begin{array}{l}\text { Engraved } \\
\text { concentric circles and hatched pendant } \\
\text { triangles+ }\end{array}$ & - & 1 & 1 \\
$\begin{array}{l}\text { circle and spiral engraved lines+ } \\
\text { cross-hatched engraved zone }\end{array}$ & - & 1 & 1 \\
curvilinear engraved lines & - & 1 & 1 \\
hatched pendant triangles & - & - & 3 \\
horizontal engraved lines \\
horizontal and sets of vertical engraved lines & $1 *$ & 1 & 1 \\
parallel engraved lines & - & 1 & 1 \\
straight engraved line & - & 1 & 1 \\
Ripley Engraved+ & - & 1 & 1 \\
Spiro Engraved & - & 1 & 1 \\
Slipped & - & 1 & 1 \\
int./ext. red-slipped & - & 13 & 14 \\
\hline Totals & 1 & & 1 \\
\hline
\end{tabular}

*comprises 11 sherds from sherd vessel section

+ Titus phase fine ware sherds

Other Early Caddo period fine ware sherds from the R. L. Jaggers site include an exquisitely engraved (concentric semi-circles and opposed diagonal and curvilinear lines, as well as excised semi-circles and triangular zones) and excised grog-tempered Spiro Engraved bottle sherd (see Figure 13a). Another bottle sherd has opposed diagonal and curvilinear engraved lines (see Figure 13e), and a grog-tempered carinated bowl sherd has a horizontal engraved line and sets of opposed vertical engraved lines (see Figure 13c).

There are three sherds from Late Caddo, Titus phase, fine ware vessels in the fine ware sherds from the site. The first is part of the lower rim of a Ripley Engraved, var. McKinney-Enis Smith (Fields et al. 2014:Table 8.6) carinated bowl. The other two fine ware sherds are from bottles, including a Ripley Engraved bottle sherd with a sun circle motif (see Figure 13b) with concentric circles and hatched pendant triangles and a Wilder Engraved bottle sherd with a central circle element and spirals (see Figure 13d).

\section{Ceramic Pipe Sherd}

There is a single ceramic pipe stem from a Red River style long-stemmed pipe (see Hoffman 1967). The pipe has been tempered with finely crushed burned bone, and was fired in a reducing environment, but cooled in the open air. The exterior pipe stem surface has been well smoothed, and has a diameter of 10.0 
$\mathrm{mm}$ as well as a $3.8 \mathrm{~mm}$ stem hole diameter. This pipe stem is likely from the Early Caddo period Miller's Crossing variety of the Red River pipe (see Hoffman 1967:9).

\section{SUMMARY AND CONCLUSIONS}

The R. L. Jaggers site is a multiple component archaeological site located along Ripley Creek in the Sulphur River basin in the East Texas Post Oak Savannah. It was investigated by the University of Texas (UT) in 1930, but has not been investigated since by professional archaeologists.

Recovered projectile points indicate that the site may first have been used prior to ca. 8000 years B.P., but there were more substantial occupations during the Late Archaic and (especially) the Woodland periods, if the proportion of Gary and Kent dart points is any indication. The chipped stone tools from the site are dominated by dart points.

The principal occupation at the R. L. Jaggers site occurred during the Early Caddo period, between ca. A.D. 1000-1200. The occupation included some habitation debris - primarily sherds from plain ware, utility ware, and fine ware vessels - and four burials; burials dating to this period are rare from non-mound sites in East Texas, so they provide unique information on the character of mortuary practices from habitation sites. Three of the burials were extended supine interments and the other was a cremation. Funerary offerings with the burials included nine vessels, two celts, four Gary dart points, and a cache of 10 pieces of lithic debris. Four other vessels were considered by UT archaeologists as isolated finds, but they likely are also funerary offerings to unrecognized burial features. The 13 vessels include seven fine ware vessels - including Spiro Engraved ( $n=4$ vessels), Hickory Engraved $(n=2)$, and an engraved-punctated bottle - four utility ware jars - including Davis Incised ( $n=2$ vessels), Kiam Incised ( $n=1$ vessel), and one incised-punctated vessel-and two plain vessels: a carinated bowl and a jar.

Hopefully the archaeological deposits at the R. L. Jaggers site are still preserved. If they are, it would be worthwhile to investigate the site again, concentrating on delimiting the habitation deposits and any structural features, and obtaining organic remains from feature contexts that can be used to obtain a series of radiocarbon dates from the site. The calibrated results of those dates can be employed to establish a more refined temporal estimate as to when during the Early Caddo period the site was occupied.

\section{ACKNOWLEDGMENTS}

Thanks are first extended to Jonathan Jarvis at the Texas Archeological Research Laboratory at the University of Texas at Austin for facilitating access to the records and collections from the R. L. Jaggers site. Thanks also to Bo Nelson for taking the vessel photographs, and to Lance Trask for preparing the remainder of the figures in this article.

\section{REFERENCES CITED}

Banks, L.

1990 From Mountain Peaks to Alligator Stomachs: A Review of Lithic Sources in the Trans-Mississippi South, the Southern Plains, and Adjacent Southwest. Memoir No. 4. Oklahoma Anthropological Society, Norman.

Brown, K. M.

1976 Fused Volcanic Glass from the Manning Formation. Bulletin of the Texas Archeological Society 47:189207. 
Fields, R. C., V. L. Hatfield, D. A. Burden, E. F. Gadus, M. C. Wilder, and K. W. Kibler

2014 Testing and Data Recovery Excavations at 11 Native American Archeological Sites along the U.S. Highway 271 Mount Pleasant Relief Route, Titus County, Texas. Reports of Investigations No. 168. Prewitt and Associates, Inc., Austin.

Hoffman, M. P.

1967 Ceramic Pipe Style Chronology Along the Red River Drainage in Southwestern Arkansas. The Arkansas Archeologist 8(1):4-14.

Jackson, A. T.

1930 Exploration of a Burial Site on R. L. Jaggers Farm in Franklin County, Texas. MS on file, Texas Archeological Research Laboratory, The University of Texas at Austin.

Perttula, T. K.

2013 Paleoindian to Middle Archaic Projectile Points from East Texas. Journal of Northeast Texas Archaeology 42:33-46.

2015 East Texas Caddo Ceramic Sherd Database. Journal of Northeast Texas Archaeology 51, in press.

Thurmond, J. P.

1990 Archeology of the Cypress Creek Drainage Basin, Northeastern Texas and Northwestern Louisiana. Studies in Archeology 5. Texas Archeological Research Laboratory, The University of Texas at Austin. 